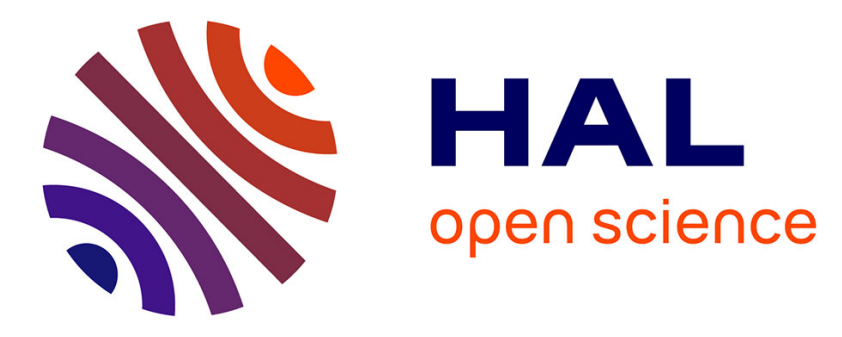

\title{
Characterization of recessive Parkinson's disease in a large multicenter study
}

Suzanne Lesage, Ariane Lunati, Marion Houot, Sawssan Ben Romdhan, Fabienne Clot, Christelle Tesson, Graziella Mangone, Benjamin Le Toullec, Thomas Courtin, Kathy Larcher, et al.

\section{To cite this version:}

Suzanne Lesage, Ariane Lunati, Marion Houot, Sawssan Ben Romdhan, Fabienne Clot, et al.. Characterization of recessive Parkinson's disease in a large multicenter study. Annals of Neurology, 2020, 88 (4), pp.843-850. 10.1002/ana.25787 . hal-02981145

\section{HAL Id: hal-02981145 \\ https://hal.science/hal-02981145}

Submitted on 27 Oct 2020

HAL is a multi-disciplinary open access archive for the deposit and dissemination of scientific research documents, whether they are published or not. The documents may come from teaching and research institutions in France or abroad, or from public or private research centers.
L'archive ouverte pluridisciplinaire HAL, est destinée au dépôt et à la diffusion de documents scientifiques de niveau recherche, publiés ou non, émanant des établissements d'enseignement et de recherche français ou étrangers, des laboratoires publics ou privés. 


\section{Characterization of recessive Parkinson's disease in a large multicenter study}

Suzanne Lesage, PhD, ${ }^{1,2,3,4}$, Ariane Lunati, MSc, ${ }^{1,2,3,4}$, Marion Houot, MSc, ${ }^{5,6}$, Sawssan Ben Romdhan, $\mathrm{PhD},{ }^{1,2,3,4,7}$, Fabienne Clot, $\mathrm{PhD},{ }^{8}$, Christelle Tesson, $\mathrm{PhD},{ }^{1,2,3,4}$, Graziella Mangone, MD, ${ }^{6}$, Benjamin Le Toullec, MSc, ${ }^{6}$, Thomas Courtin, MSc, ${ }^{1,2,3,4}$, Kathy Larcher, MSc, ${ }^{8}$, Mustapha Benmahdjoub, MD, ${ }^{9}$, Mohammed Arezki, MD, ${ }^{9}$, Ahmed Bouhouche, MD, ${ }^{10}$, Mathieu Anheim, MD, ${ }^{11,12,13}$, Emmanuel Roze, MD, ${ }^{1,2,3,4,14}$, François Viallet, MD, ${ }^{15,16}$, François Tison, MD, ${ }^{17,18,19}$, Emmanuel Broussolle, MD, ${ }^{20,21,22}$, Murat Emre, MD, ${ }^{23}$, Hasmet Hanagasi, MD, ${ }^{23}$, Basar Bilgic, MD, ${ }^{23}$, Meriem Tazir, MD, ${ }^{24}$, Mouna Ben Djebara, MD, ${ }^{25}$, Riadh Gouider, MD, ${ }^{25}$, Christine Tranchant, MD, ${ }^{11,12,13}$, Marie Vidailhet, MD, ${ }^{1,2,3,4,14}$, Eric Le Guern, MD, ${ }^{1,2,3,4,8}$, Olga Corti, PhD, ${ }^{1,2,3,4}$, Chokri Mhiri, MD, ${ }^{7}$, Ebba Lohmann, MD, ${ }^{23,26}$, Andrew Singleton, PhD, ${ }^{27}$, Jean-Christophe Corvol, MD, ${ }^{1,2,3,4,6}$, Alexis Brice, MD, ${ }^{1,2,3,4}$ for the French Parkinson disease Genetics Study Group (PDG)†

†Members listed in the Supplementary Material

Short running title: Characterization of recessive Parkinson’s disease

${ }^{1}$ Research Unit UMR_1127 at Sorbonne Université, Paris France

${ }^{2}$ Research Unit U1127 at INSERM, Paris France

${ }^{3}$ Research Unit UMR 7225 at the French National Center for Scientific Research (CNRS), Paris, France

${ }^{4}$ Institute for Brain and Spinal Cord (ICM), Paris, France

This article has been accepted for publication and undergone full peer review but has not been through the copyediting, typesetting, pagination and proofreading process which may lead to differences between this version and the Version of Record. Please cite this article as doi: 10.1002/ana.25787 
${ }^{5}$ Institute of Memory and Alzheimer's Disease (IM2A), Center of Excellence for Neurodegenerative Diseases (CoEN), AP-HP, Department of Neurology, Pitié-Salpêtrière Hospital, University Paris 6, Paris, France

${ }^{6}$ Clinical Investigation Centre Pitié Neurosciences CIC-1422, Paris, France

${ }^{7}$ Research Unit in Neurogenetics, Clinical Investigation Center (CIC) at the Habib Bourguiba Hospital-University center, Sfax, Tunisia

${ }^{8}$ Functional Unit of Molecular and Cellular Neurogenetics, Department of Genetics, AP-HP, University Hospitals of La Pitié Salpêtrière-Charles Foix, Paris, France

${ }^{9}$ Frantz Fanon Hospital, Hospital-University center of Blida, Blida, Algeria

${ }^{10}$ Research Unit in Neurology and Neurogenetics, Department of Neurology B and Neurogenetics, Faculty of Medicine and Pharmacy, Specialty Hospital ONO, Mohammed V University, Rabat, Morocco

${ }^{11}$ Department of Neurology at the University Hospitals of Strasbourg, France

${ }^{12}$ Institute of Genetics and Molecular and Cellular Biology (IGBMC), Illkirch, France

${ }^{13}$ Federation of Translational Medicine of Strasbourg (FMTS) University of Strasbourg, Strasbourg, France

${ }^{14}$ Department of Neurology, Pitié-Salpêtrière Hospital, Paris, France

${ }^{15}$ Department of Neurology, Intercommunal Hospital Center of Aix-Pertuis, Aix-en-Provence, France

${ }^{16}$ Department of Speech and Language, UMR 7309 at the French National Center for Scientific Research (CNRS) and University of Aix-Marseille, Aix-en-Provence, France 
${ }^{17}$ Department of Neurology, Pellegrin Hospital, Hospital-University center of Bordeaux, Bordeaux, France

${ }^{18}$ Institute of Neurodegenerative Diseases, University of Bordeaux, Bordeaux France

${ }^{19}$ French National Center for Scientific Research (CNRS), UMR 5293, Bordeaux, France

${ }^{20}$ University of Lyon, Institute of Cognitive Science Marc-Jeannerod, UMR 5229 at the French National Center for Scientific Research (CNRS), Bron, France

${ }^{21}$ Civil Hospices of Lyon, Neurological Hospital Pierre-Wertheimer, Department of Neurology C, Bron, France

${ }^{22}$ University of Lyon, Faculty of Medicine Lyon-Sud Charles-Mérieux, Oullins, France

${ }^{23}$ Behavioural Neurology and Movement Disorders Unit, Department of Neurology, Istanbul Faculty of Medicine, Istanbul University, Istanbul, Turkey

${ }^{24}$ Department of Neurology, Mustapha Bacha University Hospital, Algiers, Algeria

${ }^{25}$ Department of Neurology, Clinical Investigation Center, Razi University Hospital, Faculty of Medicine of Tunis, Tunisia

${ }^{26}$ Department of Neurodegenerative Diseases, Hertie Institute for Clinical Brain Research, University of Tübingen, Tübingen, Germany

${ }^{27}$ Laboratory of Neurogenetics, National Institute on Aging, National Institutes of Health, Bethesda, Maryland, USA

\section{*Correspondence to:}


Dr Suzanne Lesage and Prof. Alexis Brice INSERM U 1127, Université Pierre et Marie Curie, Institut du Cerveau et de la Moelle épinière - ICM, Hôpital de la Salpêtrière, Paris, France. E-mail: suzanne.lesage@upmc.fr; alexis.brice@icm-institute.org 


\begin{abstract}
Studies of the phenotype and population distribution of rare genetic forms of parkinsonism are required, now that gene-targeting approaches for Parkinson's disease have reached the clinical trial stage. We evaluated the frequencies of PRKN, PINK1, and DJ-1 mutations in a cohort of 1587 cases. Mutations were found in 14.1\% of patients: $27.6 \%$ were familial and $8 \%$ were isolated. PRKN was the gene most frequently mutated in Caucasians whereas PINK1 mutations predominated in Arab-Berber individuals. Patients with PRKN mutations had an earlier age at onset, and less asymmetry, levodopa-induced motor complications, dysautonomia, and dementia than those without mutations.
\end{abstract}

Keywords: Parkinson's disease; PRKN; PINK1; autosomal recessive inheritance; genotypephenotype correlations

\begin{abstract}
Abbreviations: AAO, age-at-onset; AR, autosomal recessive; EO, early-onset; GLM, generalised linear model; PD, Parkinson's disease; LRRK2, leucine-rich repeat kinase 2; PINK1, PTEN-induced putative kinase 1
\end{abstract}


Our understanding of the genetic basis of Parkinson's disease (PD) has been improved with the identification of several disease-causing genes. ${ }^{1}$ Trials targeting these genes are underway and the development of cohorts ready for precision clinical trials that target genetic forms of PD are now required. ${ }^{2,3}$

PRKN, PINK1, and DJ-1 mutations are the most frequent cause of early-onset (EO) autosomal recessive (AR) typical PD. We investigated the frequency and nature of pathogenic variants of these three genes in a cohort of 1587 PD probands, comparing clinical characteristics between patients with PRKN mutations (PRKN-PD), and those without pathogenic variants of known PD genes (PD-NM).

\section{Patients and Methods}

\section{Patient selection}

Patients were enrolled between 1990 and 2018, through the French PDG network and North African and Turkish collaborations. PD was diagnosed according to the clinical diagnostic criteria of the UK Parkinson Disease Society Brain Bank (PDSBB). ${ }^{4}$ Cases with mutations responsible for recessive atypical parkinsonism or those carrying the common $L R R K 2$ Gly2019Ser variant were not included. We selected a cohort of 1587 probands from 497 AR PD families (at least two affected siblings and isolated cases born to consanguineous parents), and 1090 isolated cases, all screened for PRKN.

Standardized neurological examinations were performed by movement disorder experts, and 28 variables were used to obtain comparable data. 
Most probands were Caucasian ( $n=1324,83.4 \%$; 927 French, 134 Turkish), Arab-Berber ( $n=213,13.4 \%$ ) or of other ethnicities ( $n=50,3.2 \%$ ). We included 1587 PD probands and 52 mutation-carrying relatives in the genotype/phenotype correlation analysis. Informed consent and approval from institutional review boards were obtained for sample collection.

\section{Procedures}

Probands were screened by denaturing high-performance liquid chromatography (dHPLC) and/or direct sequencing, ${ }^{5-8}$ next-generation sequencing (NGS) with a targeted gene panel or whole-exome sequencing ${ }^{9,10}$.

PRKN was screened in 1587 probands, PINK1 and DJ-1 in 1223. Sanger sequencing was performed to confirm variants and cosegregation analyses, where possible. Exon rearrangements were detected by semi-quantitative PCR for $P R K N^{5}$ or with the MRC Holland Salsa MLPA P051/P052 Parkinson kits. Patients with an AAO $\leq 40$ years and lymphoblastoid cells available for RT-PCR analysis $(n=15)^{5}$ or unaffected relatives for cosegregation analysis ( $n=30$ ) were investigated for possible PRKN rearrangements undetectable by MLPA.

\section{Statistical analysis}

The PD-NM and PRKN-PD groups were compared with Welch's $t$-tests for continuous variables and Fisher's exact tests for categorical variables.

We used generalized linear models (GLMs) to compare clinical features between PRKN-PD with bi-allelic or double heterozygous mutations and PD-NM, adjusting for sex, age-at-onset 
(AAO), disease duration and dopaminergic medication. We used GLMs with identity links and normal distributions for continuous clinical features, and GLMs with logit links and Bernoulli distributions for binary clinical features. Interactions between AAO and disease duration were also included. Disease duration and dopaminergic medication were not included in models for clinical features at onset. Effects were assessed in Fisher type II tests, and effect size was estimated with Cohen's f2. Benjamini-Hochberg correction for multiple testing was performed. GLMs were generated for the 15/28 clinical features for at least 20\% of the patients in each group with available data.

\section{Results}

\section{Demographic and clinical data}

In our cohort, men $(n=951,60 \%)$ and EO cases (mean AAO 40.2 [SD 12.1] years) were overrepresented, particularly among isolated cases $(p<0.0001)$ (Table 1$)$.

\section{Distribution and nature of recessive PD-associated gene mutations}

Bi-allelic or double heterozygous mutations of known AR PD-causing genes were present in 224 of the 1587 probands (14.1\%): 27.6\% (137/497) of familial and 8\% (87/1090) of isolated cases. The most frequently mutated genes were PRKN (199/1587, 12.5\%), then PINK1 (23/1223, 1.9\%), and $D J-1$ (2/1223, 0.16\%). We identified 56 patients with single heterozygous variants in the three genes in whom AAO was significantly later than cases with bi-allelic or double heterozygous mutations (36.9 [SD 10.6] vs. 31.3 [SD 11.1], $p=0.0009$ ); they were removed from genotype/phenotype correlation analyses. 
The 199 cases carried either homozygous $(n=92)$, or compound heterozygous $(n=59)$, confirmed by segregation analysis of all available unaffected relatives or double heterozygous (n=48) PRKN mutations for whom phasing was still unknown. These carriers displayed 77 different variants, including 19 absent from public databases (www.mdsgene.org) ${ }^{11}$ (Fig 1A). RT-PCR identified a single French family with PRKN Ex3del/Ex3dup compound heterozygous rearrangements not detectable by MLPA but elucidated by co-segregation analysis.

Most of the 23 probands with pathogenic PINK1 variants were Arab-Berbers ( $n=12,52.2 \%$ ); 8 carried the homozygous Gln456* mutation. Most variants were homozygous ( $n=18,78.3 \%)$. We identified 21 different pathogenic variants, including three not in databases (Fig 1B).

\section{Distribution of PRKN and PINK1 mutation carriers by age-at-onset, pattern of presentation and ethnicity}

The proportion of probands with PRKN mutations decreased with increasing AAO: $42.2 \%$ for an AAO $\leq 20$ years, $29 \%$ (21 to 30 years), $13 \%$ (31 to 40 years), and $4.4 \%$ (41 to 60 years)

(Fig 2A). This decrease was more marked in isolated than familial cases (Fig 2B). PINK1 mutations were less frequent than PRKN mutations (1.9\% vs. 12.5\%) but more evenly distributed among familial cases for AAOs up to 60 years. Neither PRKN nor PINK1 variants were found in patients with onset after 60 (Fig 2A-D). PRKN mutations were more frequent in Caucasians (179/1324, 13.5\%) than in Arab-Berbers (16/213, 7.5\%) (Fig 2E). Conversely, PINK1 mutations were more common in Arab-Berbers (12/188, 6.4\%) than Caucasians (9/1005, 0.9\%) (Fig 2E). 


\section{Comparison of PRKN mutation carriers (PRKN-PD) with non-mutation carriers (PD-}

NM): genotype-phenotype correlations

We compared the clinical features between the 228/241 PRKN-PD and 1181/1307 PD-NM subjects without missing data (Table 2; Supplementary Table 1). The proportion of men $\left(p_{a d j}=0.016\right)$ and AAO $\left(p_{a d j}<0.0001\right)$ were greater in the PD-NM than the PRKN-PD group. Dopaminergic treatment was similar between groups ( $\left.p_{a d j}=0.69\right)$, but levodopa responsiveness was higher in PRKN-PD than PD-NM ( $\left.p_{a d j}=0.045\right)$.

After adjustment for covariables, $P R K N$-PD had a higher initial frequency of tremor $\left(p_{a d j}=0.0076\right)$, but lower frequencies of akinesia $\left(p_{a d j}=0.0003\right)$, micrographia $\left(p_{a d j}=0.010\right)$, and asymmetry $\left(p_{a d j}=0.0005\right)$ than PD-NM patients (Table 2). Dystonia at onset and cardinal symptom (bradykinesia, rest tremor and rigidity) frequencies were similar in both groups. Motor severity after adjustment for disease duration was lower in PRKN-PD than in PD-NM (UPDRS score, $p_{a d j}=0.014$ ), and $P R K N$-PD patients developed fewer levodopa-induced motor complications (dyskinesia: $p_{a d j}=0.0005$; motor fluctuations: $p_{a d j}<0.0001$ ). Non-motor symptoms, including dysautonomia $\left(p_{a d j}<0.0001\right)$ and dementia $\left(p_{a d j}=0.014\right)$, were less frequent in $P R K N$-PD patients.

\section{Mutational and phenotypic characteristics of PINK1 and DJ-1 mutation carriers}

The PINK1-associated phenotype of the 33 carriers resembled that of $P R K N$, but with a slightly later AAO (mean 34.6 [SD 12.2] years vs. 31.3 [SD 10.9] years; $p=0.20$ ), a lower 
frequency of tremor $(16.7 \%$ vs. $68.5 \%$; $p=0.0005)$ and a higher rate of dystonia $(90 \%$ vs. $18.2 \% ; p<0.0001$ ) at onset (Supplementary Table 2). Non-motor symptoms, such as dysautonomia (72.2\% vs. 19.6\%; $p<0.0001)$ and dementia (25\% vs. $3.8 \%$; $p=0.0007)$ were more frequent in patients with PINK1 variants, who were also more likely to display levodopa-induced dyskinesia (93.3\% vs. 54.1\%; $p=0.0024)$ and motor fluctuations $(66.7 \%$ vs. 46.2\%; $p=0.06)$.

The two pathogenic $D J-1$ variant carriers (one Caucasian, one North African) each carried a previously unknown homozygous Glu94* and a compound heterozygous variant affecting the same highly conserved amino acid (Thr154Ile/Thr154Ala). They developed PD, with the four cardinal signs, at the ages of 29 and 28. Dystonia at onset, dyskinesia and orthostatic hypotension were noted in one patient, without cognitive signs.

\section{Discussion}

We established the spectrum and relative frequencies of mutations in a large cohort of AR PD cases, elucidating the genotype-clinical phenotype relationship. Homozygous/compound or double heterozygous pathogenic variants of PRKN, PINK1, and DJ-1 account for $14.1 \%$ of our PD patients, with $P R K N$ the most frequently mutated. This study included a large number of genotyped and extensively phenotyped patients (276 mutation carriers) compared with a group of cases not carrying mutations of known AR PD-causing genes. However, the clinical data were cross-sectional, the numbers of patients with mutations of genes other than PRKN were small, and our populations were biased towards EO cases. In addition, 24\% (48/199) of 
our PD patients with two PRKN mutations lacked information on their mutational phasing. However, given that we found no mutations in cis in a co-segregation analysis of 59 index cases, we are confident that the vast majority of patients with two mutations carry them in trans. Nevertheless, our findings may have major implications for patient selection for genetic testing based on AAO, pattern of disease presentation, and ethnicity. Indeed, the frequency of pathogenic variants of AR PD-associated genes i) decreased with increasing AAO, to zero for an AAO beyond 60 years, ii) in cases with a positive family history or consanguinity was more than triple that in isolated cases, and iii) was much higher for PRKN than PINK1 in Caucasians, but similar for these two genes in Arab-Berbers. However, pathogenic PRKN variants were more frequent in our EO PD cases ( $<50$ years, 190/1273, 14.9\%) than in four other cohorts $\left(10.1 \%\right.$ in a Taiwanese cohort ${ }^{12}$ and $2.8 \%$ in a Norwegian cohort $^{13}$, both with EO defined as $<45$ years; $5.9 \%$ in a UK series ${ }^{14}$ and $2.8 \%$ in a larger multicenter sample ${ }^{15}$, both with EO $<50$ years). A meta-analysis of more than $5800 \mathrm{PD}$ patients, found PRKN variants in $8.6 \%$ of PD cases with an AAO $<50 .{ }^{15}$ We provide more precise data for $P R K N$ and PINK1 genes, according to AAO.

GLM analyses revealed that AAO was lower, disease progression slower and the response to levodopa stronger in patients with $P R K N$ mutations than in those without pathogenic variants, as previously reported. ${ }^{12,15,16,17}$ However, these mutations were not associated with higher rates of dystonia at onset, a trait more strongly associated with EO (see Supplementary Table 1) than with genetic status. Patients with $P R K N$ mutations also had a distinctive non-motor symptom profile, with lower frequencies of dementia and dysautonomia, consistent with previous reports. ${ }^{18}$ After adjustment for disease duration and dopaminergic medication, these 
patients had fewer treatment-induced complications, such as dyskinesia and motor fluctuations, than PD-NM patients. This very pure and slowly progressive phenotype makes patients with $P R K N$ variants, very good candidates for deep-brain stimulation (DBS). ${ }^{19,20}$

The causal gene(s) remained unidentified for a number of families with AR PD ( 72.5\%), suggesting that pathogenic variants of known genes may have been missed or the involvement of unknown genes.

These findings will help to guide routine genetic testing and to establish cohorts of patients for clinical trials targeting the gene defects or their physio-pathological consequences. 


\section{Supplementary Materials}

This file includes:

Supplementary Table 1

Supplementary Table 2

Supplementary Table 3

\section{Acknowledgement}

We thank the patients and their families. We thank the DNA and Cell Bank of the ICM Brain Institute for sample preparation. This work was supported by the Fondation de France, France-Parkinson Association, la Fédération pour la Recherche sur le Cerveau (FRC) and the French program “Investissements d'avenir” (ANR-10-IAIHU-06). This work was supported in part by the Intramural Research Program of the National Institute on Aging, National Institutes of Health, Department of Health and Human Services; project number ZO1 AG000949.

\section{Author Contributions}

SL, J-CC, and AB contributed to the conception and design of the study. All authors contributed to the acquisition and analysis of data. SL, AL, MH, CT, ER, J-CC, AB contributed to the drafting of the text and figure preparation.

\section{Potential Conflicts of Interest}


None to report.

\section{References}

1 Lunati A, Lesage S, Brice A. The genetic landscape of Parkinson's disease. Rev Neurol (Paris) 2018;174:628-643.

2 Strafella C, Caputo V, Galota MR, et al. Application of Precision Medicine in Neurodegenerative Diseases. Front Neurol 2018;9:701.

3 Vollstedt EJ, Kasten M, Klein C; MJFF Global Genetic Parkinson's Disease Study Group. Using global team science to identify genetic parkinson's disease worldwide. Ann Neurol 2019;86:153-157.

4 Hughes AJ, Daniel SE, Kilford L, Lees AJ. Accuracy of clinical diagnosis of idiopathic Parkinson's disease: a clinico-pathological study of 100 cases. J Neurol Neurosurg Psychiatry 1992;55:181-184.

5 Lesage S, Magali P, Lohmann E, et al. Deletion of the parkin and PACRG gene promoter in early-onset parkinsonism. Hum Mutat 2007;28:27-32.

6 Ibáñez P, Lesage S, Lohmann E, et al. Mutational analysis of the PINK1 gene in earlyonset parkinsonism in Europe and North Africa. Brain 2006;129:686-694. 
7 Leutenegger AL, Salih MA, Ibáñez P, et al. Juvenile-onset Parkinsonism as a result of the first mutation in the adenosine triphosphate orientation domain of PINK1. Arch Neurol 2006;63:1257-1261.

8 Lohmann E, Dursun B, Lesage S, et al. Genetic bases and phenotypes of autosomal recessive Parkinson disease in a Turkish population. Eur J Neurol 2012;19:769-775.

9 Bouhouche A, Tesson C, Regragui W, et al. Mutation analysis of consanguineous Moroccan patients with Parkinson's disease combining microarray and gene panel. Front Neurol 2017;8:567.

10 Lesage S, Drouet V, Majounie E, et al. Loss of VPS13C function in autosomalrecessive Parkinsonism causes mitochondrial dysfunction and increases PINK1/Parkin-dependent mitophagy. Am J Hum Genet 2016;98:500-513.

11 Kasten M, Hartmann C, Hampf J, et al. Genotype-phenotype relations for the Parkinson's disease genes Parkin, PINK1, DJ1: MDSGene Systematic. Mov Disord 2018;33:730-741.

12 Lin $\mathrm{CH}$, Chen PL, Tai $\mathrm{CH}$, et al. A clinical and genetic study of early-onset and familial parkinsonism in Taiwan: An integrated approach combining gene dosage analysis and next-generation sequencing. Mov Disord 2019;34:506-515.

13 Gustavsson EK, Trinh J, McKenzie M, et al. Genetic identification in early onset Parkinsonism among Norwegian Patients. Mov Disord Clin Pract 2017;4:499-508.

14 Kilarski LL, Pearson JP, Newsway V, et al. Systematic review and UK-based study of PARK2 (parkin), PINK1, PARK7 (DJ-1) and LRRK2 in early-onset Parkinson's disease. Mov Disord 2012;27:1522-1529. 
15 Marder KS, Tang MX, Mejia-Santana H, et al. Predictors of parkin pathogenic variants in early-onset Parkinson disease: the consortium on risk for early-onset Parkinson disease study. Arch Neurol 2010;67:731-738.

16 Lohmann E, Periquet M, Bonifati V, et al. How much phenotypic variation can be attributed to parkin genotype? Ann Neurol 2003;54:176-185.

17 Khan NL, Graham E, Critchley P, et al. Parkin disease: a phenotypic study of a large case series. Brain 2003;126:1279-1292.

18 Alcalay RN, Caccappolo E, Mejia-Santana H, et al. Cognitive and motor function in long-duration PARKIN-associated Parkinson disease. JAMA Neurol 2014;71:62-67.

19 Pal GD, Hall D, Ouyang B, et al. Genetic and clinical predictors of deep brain stimulation in young-onset Parkinson's disease. Mov Disord Clin Pract 2016;3:465471.

20 Rizzone MG, Martone T, Balestrino R, Lopiano L. Genetic background and outcome of deep brain stimulation in Parkinson's disease. Parkinsonism Relat Disord 2018;64:8-19. 


\section{Figure Legends}

FIGURE 1: Schematic representation of the (A) PRKN and (B) PINK1 genes and respective proteins and associated disease-linked mutations.

Exonic deletions (in red), duplications (in green), or triplications (in blue) are shown in the upper panel and point mutations (missense, frameshift, nonsense, and splice) are shown in the lower panel. Newly identified mutations are shown in bold. Numbers in brackets indicate the number of mutation carriers. PRKN cDNA numbering: NM_004562.2; PINK1 cDNA numbering: NM_032409.2.

Parkin protein: UBL, ubiquitin-like; RING, really interesting new gene; IBR, in-between RING; PINK1 protein: MTS, mitochondrial targeting sequence; TM, transmembrane helix.

FIGURE 2: Distribution of PRKN and PINK1 mutation carriers by age-at-onset, pattern of disease presentation and ethnicity. (A) Proportion of probands, by age-at-onset, for PRKN (199 carriers among 1587 probands). (B) Proportion of PRKN mutation carriers from 497 cases with autosomal recessive PD (in blue) vs. 1090 isolated cases (in orange) by age-atonset and pattern of presentation of PD. (C) Proportion of probands, by age-at-onset for PINK1 (23 carriers among 1223 probands). (D) Proportion of PINK1 mutation carriers from 386 cases with autosomal recessive PD (in blue) vs. 837 isolated cases (in orange) by age-atonset and pattern of presentation of PD. (E) Proportion of PRKN and PINK1 mutation carriers, according to their ethnicity: Caucasians ( $n=1324$, in blue) or Arab-Berbers $(n=213$, in orange) 
TABLE 1. Demographic data for our study population

\begin{tabular}{|c|c|c|c|c|c|c|c|}
\hline & $\begin{array}{l}\text { Whole PD } \\
\text { group }\end{array}$ & $n$ & $\begin{array}{l}\text { AR PD, including } \\
\text { isolated cases } \\
\text { with } \\
\text { consanguinity }\end{array}$ & $n$ & $\begin{array}{l}\text { Isolated } \\
\text { cases }\end{array}$ & $n$ & $\begin{array}{l}\text { AR PD vs. } \\
\text { isolated case } \\
p \text { value }\end{array}$ \\
\hline \% men (n) & $60.0(951)$ & 1587 & $57.1(284)$ & 497 & $61.2(667)$ & 1090 & 0.14 \\
\hline Eth nic background & & 1587 & & 497 & & 1090 & $<0.0001^{*}$ \\
\hline \% Caucasian (n) & 83.4 (1324) & & 75.5 (375) & & $87.1(949)$ & & \\
\hline \% Arab-Berbers (n) & $13.4(213)$ & & $22.1(110)$ & & $9.4(103)$ & & \\
\hline \% others/mixed (n) & $3.2(50)$ & & $2.4(12)$ & & $3.5(38)$ & & \\
\hline \% Consanguinity (n) & $12.9(202)$ & 1564 & $40.9(202)$ & 494 & 0 & 1070 & NA \\
\hline Ag -at-onset (SD), y & $40.2(12.1)$ & 1543 & $43.8(15.0)$ & 485 & $38.6(10.1)$ & 1058 & $<0.0001^{*}$ \\
\hline ige & $2-81$ & & $3-81$ & & $2-74$ & & \\
\hline Age at examination (SD), y & $49.7(13.2)$ & 1575 & $54.2(14.5)$ & 495 & $47.7(12.0)$ & 1080 & $<0.0001^{*}$ \\
\hline ge & $9-87$ & & $16-87$ & & $9-79$ & & \\
\hline ease duration (SD), y & $9.8(8.6)$ & 1530 & $10.9(9.6)$ & 482 & $9.2(8.0)$ & 1048 & $0.0005^{*}$ \\
\hline Range & $0-63$ & & $0-63$ & & $0-48$ & & \\
\hline
\end{tabular}

Frequencies were compared in Fisher's exact tests for qualitative traits and means were compared in t-tests for continuous variables.

$* p<0.05$

NA, Not appropriate. 
TABLE 2. Demographic and clinical characteristics of patients with Parkinson's disease with pathogenic PRKN variants (PRKN-PD) and of patients without pathogenic variants (PD-NM)

\begin{tabular}{|c|c|c|c|c|c|c|c|c|}
\hline \multirow[b]{2}{*}{ Characteristics } & \multicolumn{4}{|c|}{ PD-NM and $P R K N$-PD unadjusted comparisons } & \multicolumn{4}{|c|}{ PD-NM and $P R K N$-PD adjusted comparisons } \\
\hline & $\begin{array}{l}\text { PD-NM } \\
n=1181\end{array}$ & $\begin{array}{l}P R K N-P D \\
n=228\end{array}$ & $p$ value & $\begin{array}{l}p \text { value } \\
\text { adjusted } ¥\end{array}$ & $\begin{array}{l}\text { Coefficient or } \\
\text { odds ratio } \\
\text { (OR) (SE) }\end{array}$ & $\begin{array}{l}\text { Cohen's } \\
\text { f2 }\end{array}$ & $p$ value & $\begin{array}{l}p \text { value } \\
\text { adjusted } ¥\end{array}$ \\
\hline \multicolumn{9}{|l|}{ Baseline } \\
\hline Sex (\% male) & $\begin{array}{l}727 / 1181 \\
(61.6 \%)\end{array}$ & $\begin{array}{l}118 / 228 \\
(51.8 \%)\end{array}$ & $0.0063 *$ & $0.016^{*}$ & & & & \\
\hline $\begin{array}{l}\text { Age at } \\
\text { examination } \\
\text { (SD), y }\end{array}$ & $50.5(13.2)$ & $45.4(12.9)$ & $<0.0001^{*}$ & $<0.0001^{*}$ & & & & \\
\hline $\begin{array}{l}\text { Disease duration } \\
\text { (SD), y }\end{array}$ & $8.8(7.8)$ & $14.1(10.4)$ & $<0.0001^{*}$ & $<0.0001^{*}$ & & & & \\
\hline $\begin{array}{l}\text { Age-at-onset } \\
\text { (SD), y }\end{array}$ & $41.6(12.0)$ & $31.2(10.7)$ & $<0.0001^{*}$ & $<0.0001^{*}$ & & & & \\
\hline L-DOPA-treated & $\begin{array}{l}791 / 1181 \\
(67 \%)\end{array}$ & $\begin{array}{l}148 / 228 \\
(64.9 \%)\end{array}$ & 0.54 & 0.69 & & & & \\
\hline $\begin{array}{l}\text { Levodopa } \\
\text { responsiveness }\end{array}$ & $\begin{array}{l}659 / 738 \\
(89.3 \%)\end{array}$ & $\begin{array}{l}142 / 149 \\
(95.3 \%)\end{array}$ & $0.022^{*}$ & $0.045^{*}$ & $1.9(0.82)$ & 0.007 & 0.11 & 0.15 \\
\hline \multicolumn{9}{|c|}{ Motor symptoms and signs } \\
\hline Dystonia at onset & $\begin{array}{l}164 / 990 \\
(16.6 \%)\end{array}$ & $\begin{array}{l}37 / 201 \\
(18.4 \%)\end{array}$ & 0.54 & 0.69 & $0.84(0.18)$ & 0.001 & 0.42 & 0.46 \\
\hline Akinesia at onset & $\begin{array}{l}590 / 946 \\
(61.3 \%)\end{array}$ & $\begin{array}{l}99 / 206 \\
(48.1 \%)\end{array}$ & $0.0002 *$ & $0.0010^{*}$ & $0.51(0.09)$ & 0.015 & $0.0001 *$ & $0.0003 *$ \\
\hline Tremor at onset & $\begin{array}{l}570 / 960 \\
(59.4 \%)\end{array}$ & $\begin{array}{l}142 / 205 \\
(69.3 \%)\end{array}$ & $0.0091 *$ & $0.021^{*}$ & $1.7(0.29)$ & 0.007 & $0.0030^{*}$ & $0.0076^{*}$ \\
\hline $\begin{array}{l}\text { Micrographia at } \\
\text { onset }\end{array}$ & $\begin{array}{l}308 / 927 \\
(33.2 \%)\end{array}$ & $\begin{array}{l}42 / 204 \\
(20.6 \%)\end{array}$ & $0.0003^{*}$ & $0.0013^{*}$ & $0.58(0.11)$ & 0.007 & $0.0047^{*}$ & $0.010^{*}$ \\
\hline Asymmetry & $\begin{array}{l}1001 / 1035 \\
(96.7 \%)\end{array}$ & $\begin{array}{l}181 / 198 \\
(91.4 \%)\end{array}$ & $0.0016^{*}$ & $0.0049 *$ & $0.26(0.09)$ & 0.010 & $0.0002 *$ & $0.0005 *$ \\
\hline Bradykinesia & $\begin{array}{l}1033 / 1069 \\
(96.6 \%)\end{array}$ & $\begin{array}{l}201 / 208 \\
(96.6 \%)\end{array}$ & 1.0000 & 1.0000 & $1.4(0.63)$ & 0.002 & 0.43 & 0.46 \\
\hline Rigidity & $\begin{array}{l}1008 / 1066 \\
(94.6 \%)\end{array}$ & $\begin{array}{l}194 / 204 \\
(95.1 \%)\end{array}$ & 0.87 & 0.90 & $1.1(0.42)$ & $<0.001$ & 0.77 & 0.77 \\
\hline Tremor & $\begin{array}{l}796 / 1056 \\
(75.4 \%)\end{array}$ & $\begin{array}{l}168 / 205 \\
(82 \%)\end{array}$ & $0.031^{*}$ & 0.057 & $1.5(0.32)$ & 0.002 & $0.048 *$ & 0.072 \\
\hline $\begin{array}{l}\text { UPDRS-Part III } \\
\text { ON (SD) }\end{array}$ & $19.6(13.8)$ & $15.9(11.9)$ & $0.0017 *$ & $0.0049 *$ & $-3.3(1.2)$ & 0.008 & $0.0081 *$ & $0.014^{*}$ \\
\hline $\begin{array}{l}\text { Hoehn\&Yahr ON } \\
\text { (SD) }\end{array}$ & $2(0.91)$ & $2.00(0.93)$ & 0.61 & 0.74 & $-0.14(0.09)$ & 0.003 & 0.13 & 0.16 \\
\hline Dyskinesia & $\begin{array}{l}457 / 667 \\
(68.5 \%)\end{array}$ & $\begin{array}{l}97 / 178 \\
(54.5 \%)\end{array}$ & $0.0007 *$ & $0.0025^{*}$ & $0.44(0.09)$ & 0.020 & $0.0001 *$ & $0.0005 *$ \\
\hline $\begin{array}{l}\text { Motor } \\
\text { fluctuations }\end{array}$ & $\begin{array}{l}485 / 663 \\
(73.2 \%)\end{array}$ & $\begin{array}{l}82 / 177 \\
(46.3 \%)\end{array}$ & $<0.0001 *$ & $<0.0001^{*}$ & $0.32(0.07)$ & 0.041 & $<0.0001^{*}$ & $<0.0001 *$ \\
\hline \multicolumn{9}{|c|}{ Non-motor symptoms and signs } \\
\hline Dysautonomia & $\begin{array}{l}254 / 470 \\
(54.0 \%)\end{array}$ & $\begin{array}{l}36 / 192 \\
(18.8 \%)\end{array}$ & $<0.0001 *$ & $<0.0001^{*}$ & $0.19(0.05)$ & 0.095 & $<0.0001 *$ & $<0.0001^{*}$ \\
\hline Dementia & $\begin{array}{l}67 / 667 \\
(10.0 \%) \\
\end{array}$ & 6/153 (3.9\%) & $0.017^{*}$ & $0.037 *$ & $0.34(0.16)$ & 0.009 & $0.0087 *$ & $0.014^{*}$ \\
\hline
\end{tabular}

Data are expressed as mean (standard deviation) for continuous variables, and as counts (percentages) for categorical variables. We used $t$-tests to compare the two groups for continuous variables and Fisher's exact tests for binary variables. 
Coefficients for continuous clinical features and odds ratios (ORs) for binary clinical features and standard error (SE), Cohen's $\mathrm{f} 2$ and $p$-values were calculated from GLMs with mutation status, sex, age-at-onset, disease duration, L-DOPA group and age-at-onset vs. disease duration for all 15 variables except for onset variables for which only mutation status, sex and age-at-onset were added. Linear models were used for continuous variables; GLMs with logit links and Bernouilli distributions were used for binary variables

${ }^{\#}$ Levodopa responsiveness was defined as a $>30 \%$ improvement in subjective perceived motor symptoms

$¥ p$ corrected for multiple testing by the Benjamini-Hochberg procedure

$* p<0.05$ 


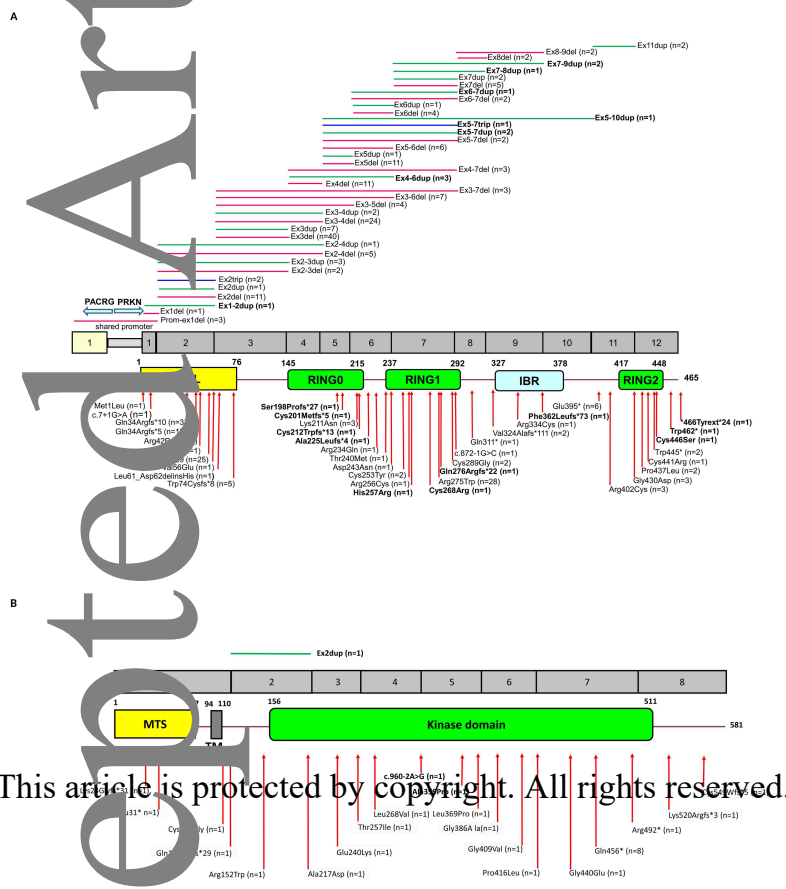


